\title{
MEMORIES OF GEORGE BARTON
}

\section{Hon Christopher Finlayson*}

This address was given by the Attorney-General, the Hon Christopher Finlayson, at the special sitting of the High Court in Wellington to honour Dr George Barton QC on Wednesday 6 July 2011.

May it please the Court:

I am pleased that the bench and bar have this opportunity to pay our last respects to George Paterson Barton QC, who died in Wellington a few weeks ago. That we are here this afternoon is because of your Honour the Chief Justice. On behalf of the legal profession, I express my thanks to you for your kindness in arranging this event, which means a lot to all of us.

It is appropriate that today's sitting is in this courtroom, where George Barton argued so many cases over the years. There are, of course, too many to outline here.

It was in this courtroom that he stood next to the former Solicitor-General, Richard Wild, in an alcove alongside a corner of the bench to watch the then RB Cooke QC cross-examine Phil Holloway in Truth Media Ownership $v$ Holloway. ${ }^{1}$ It was here that he was called to the inner bar in a special ceremony organised by the then Chief Justice, Sir Thomas Eichelbaum. And it is here where today we place on record our appreciation for his friendship and wise counsel over many years.

There are a number of speakers this afternoon and we will all be addressing various aspects of the wonderful contribution made to the law by George Barton, both here and abroad. I want to focus

* Chris Finlayson is Attorney-General of New Zealand. He was admitted as a barrister and solicitor in February 1981. He was a partner at Brandon Brookfield from 1986 to 1990 and then at Bell Gully from 1991 to 2003. He has appeared in all courts of New Zealand, including the Privy Council and Supreme Court. Before entering Parliament, he was for many years an honorary lecturer in the Law Faculty of Victoria University of Wellington, teaching civil procedure, conflict of laws, intellectual property and ethics. He served as Law Society representative on the New Zealand Council of Law Reporting from 1990 until 1998 and the New Zealand Council of Legal Education from 1992 until 1998. He served as Law Society representative on the High Court Rules Committee and still plays an active role on the Committee as Attorney-General. From 1984 to 2008 he was a co-author of McGechan on Procedure (looseleaf ed, Brookers), the leading New Zealand text on the practice and procedure of the courts of New Zealand and was the founding editor of the Procedure Reports of New Zealand.

1 Truth (NZ) Ltd v Holloway [1960] NZLR 69 (CA). 
on George Barton, the fearless advocate, who maintained the highest traditions of courage and independence at the bar over a lifetime of service.

Before I do that, however, I want to reminisce just a little about my friendship with George Barton and to place on record how much he meant to me. In giving these reminiscences, I am doing no more than saying they are perhaps a representative sample of the reminiscences of all those present. Many people, in so many areas of the law, counted him as a trusted advisor and friend.

George Barton never taught me law, although I was aware of his towering presence in my first year at Victoria University of Wellington. I remember learning about his novel way of teaching civil procedure. Dr Barton was, at one time, a lecturer in civil procedure at Victoria University of Wellington. The Government Printer refused to make copies of the old Code of Civil Procedure (the forerunner of the High Court Rules) available, so Dr Barton commenced proceedings in the name of the Victoria University of Wellington Students' Association against the Government Printer and sought a writ of mandamus. ${ }^{2}$ He lost the case and appealed to the Court of Appeal. ${ }^{3}$ The law report says simply that the members of the Court of Appeal delivered judgments affirming the judgment of the Supreme Court. What a novel way of explaining to students the interstices of civil procedure teaching by suing!

I met George Barton when I became a law clerk at Brandons in 1980. He had a suite of rooms in that building and was a close friend of my first boss, Peter McKenzie.

In 1981, George and Peter were on opposite sides of an appeal to the Court of Appeal in a case called Fuller $v$ MacLeod, which concerned the nature and extent of the common law rights of a frontager of access to the highway. ${ }^{4}$

The property in question was situated at 25 Homewood Avenue, Karori. Marion Frater, later Justice Frater of this Court, was Dr Barton's research assistant and she and I had to work on a joint memorandum for the Court on roading legislation in the Wellington province to the modern day. Contrary to what some people in this Court may think, it was a very interesting piece of work, digging out old provincial Ordinances and ancient legislation, most of which could be done in the

2 Victoria University of Wellington Students Association Inc v Shearer (Government Printer) [1973] 2 NZLR 21 (SC Wellington).

3 Victoria University of Wellington Students Association Inc v Shearer (Government Printer) [1974] 2 NZLR 138 (CA).

4 Fuller v MacLeod [1981] 1 NZLR 390 (CA). This volume also contains the following cases where Dr Barton was leading counsel: Danneverke Borough Council v Governor-General [1981] 1 NZLR 129 (HC); New Zealand Educational Institute $v$ Director-General of Education [1981] 1 NZLR 538 (CA); Environmental Defence Society Inc v South Pacific Aluminium Ltd (No 2) [1981] 1 NZLR 153 (CA); Environmental Defence Society Inc v South Pacific Aluminium Ltd (No 3) [1981] 1 NZLR 216 (CA); Re Erebus Royal Commission [1981] 1 NZLR 614 (CA); Air New Zealand Ltd v Mahon [1981] 1 NZLR 618 (CA); Ashby v Minister of Immigration [1981] 1 NZLR 222 (CA). 
flick of a switch these days because of the internet. In the early 1980s, it was a somewhat more manual task.

That case was my introduction to the finest traditions of the bar. While George and Peter were on opposite sides of the case, there was never any rancour and they got on as famously as always. One wonders whether it would be possible to agree to such a joint memorandum today. One can imagine interminable haggling over the effect of an 1865 provincial Ordinance or some other such pettifogging nonsense.

For the record, Peter McKenzie won.

Peter McKenzie and George Barton had been involved in many cases over the years, including some fascinating litigation for what was then known as the Social Credit Political League.

The genesis of the litigation was a dispute in the Nelson branch of the League. Mr O'Brien had been party leader but resigned in 1972 when he was replaced by Bruce Beetham. Thereafter, much of the energies of the League were directed to defending proceedings commenced by Mr O'Brien, whose lawyer was none other than WV Gazely of Taylor $v$ Black fame. ${ }^{5}$

Every time a case was struck out, Mr O'Brien commenced another proceeding. As I said, George and Peter were involved in defending those proceedings. I often reflect on the very real contribution to this nation's political affairs by the League. The League's contribution was most noteworthy in the areas of res judicata, dismissing motions for new trials and setting aside notices of discontinuance. ${ }^{6}$

The final case I want to mention involves the former Chief Auditor of Samoa. It perfectly illustrates George Barton's defence of the underdog. The Auditor had produced a report which displeased his political masters and he was suspended. He thereupon commenced a proceeding against the Government and was dismissed. George had a few rounds in the Supreme Court of Appeal of Samoa and then I went to Apia in 1998 for an interlocutory hearing. We have been waiting 13 years for the judgment.

There are so many reminiscences it would be selfish to outline any more. I am but one of a large cohort of the Wellington profession who met George Barton at Parsons on a regular basis for a discussion on difficult questions or, more frequently, for gossip. George loved gossip. After I returned from the Privy Council in Green v Broadcasting Corporation of New Zealand, ${ }^{7}$ I rang him

5 Taylor v Black HC Wellington CP157/92, 4 October 1992; Taylor v Black HC Wellington CP157/92, 20 July 1994; Taylor v Black HC Wellington CP157/92, 1 November 1994; Black v Taylor [1993] 3 NZLR 403 (CA).

$6 \quad$ O'Brien v New Zealand Social Credit Political League Inc [1984] 1 NZLR 63 (CA); O'Brien v New Zealand Social Credit Political League Inc (No 2) [1984] 1 NZLR 68 (CA); New Zealand Social Credit Political League Inc v O'Brien [1984] 1 NZLR 84 (CA).

7 Green v Broadcasting Corporation of New Zealand [1989] 3 NZLR 18 (PC). 
to say I was back and to report on the hearing. I was met with the phrase, which I am sure many other practitioners have heard: "The Buttery in five minutes; I want chapter and verse".

As I said, everyone in this room has these memories. They are precious to all of us, more precious than for any other lawyer. We are all very sad that he has gone. The common remark after his death was "But we thought he was indestructible". The memories we all have will never fade.

The only other thing I wanted to mention this afternoon was that, for all of us, George Barton was a fearless advocate. He ran cases others preferred to avoid. Other counsel will speak about his landmark wins in Fitzgerald v Muldoon, ${ }^{8}$ Lesa v Attorney-General, ${ }^{9}$ and the Europa tax cases. ${ }^{10} \mathrm{All}$ I want to say about Fitzgerald $v$ Muldoon is that the obituary in the Dominion Post a few weeks ago had it wrong. I have it on excellent authority that Sir Robert Muldoon did not loathe George Barton. He was apparently the only lawyer Sir Robert ever admired.

As I said the morning after George died, no greater contribution can be made to justice than by a fiercely independent member of the bar who will take on unpopular cases or act for unpopular litigants.

There have always been lawyers prepared to take the cases of unpopular clients. This is the tradition of John Cooke, who prosecuted Charles I for treason; the tradition of John Adams, who defended five British soldiers accused of murder in Boston; and, here in New Zealand, the tradition of PJ O'Regan, who defended Bishop Liston in 1922.

George Barton was a lawyer of this mould, first and foremost a servant of the law, a fearless advocate in the finest tradition of the bar who, throughout his career, exhibited qualities of excellence, fortitude and independence.

Today we say goodbye to a leader of the bar, an outstanding teacher, a mentor to many and a man highly respected by all. We will all miss him greatly but we will never forget him.

8 Fitzgerald v Muldoon [1976] 2 NZLR 615 (SC Wellington).

9 Lesa v Attorney-General [1982] 1 NZLR 165 (CA).

10 Europa Oil (NZ) Ltd v Commissioner of Inland Revenue (1973) 3 ATR 512 (SC Wellington); Europa Oil (NZ) Ltd (No 2) v Commissioner of Inland Revenue [1974] 2 NZLR 737 (CA); Europa Oil (NZ) Ltd v Commissioner of Inland Revenue [1976] 1 NZLR 546 (PC). 